\title{
To the Beat of Their Own Drum: Women in Salsa
}

\author{
Delia POEY \\ Florida State University \\ Department of Modern languages and Linguistics \\ dpoey@fsu.edu
}

\begin{abstract}
Salsa music is a Pan-Latino form of cultural expression born of an American experience. While its roots are varied-primarily but not exclusively Cuban and Puerto Rican, it mixes tradition and innovation, privileging mixture. Although much has been written about Salsa in the last fifteen years, the contributions of women as performers have been large ignored. This paper attempts to fill in that gap by arguing that Salsa, as an American music, was enriched by early contributions of two female performers, Celia Cruz and La Lupe. By engaging with the music scene in New York, these women reinvented themselves as Salsa stars in the 1960s and early 70s. Their stage performances and personas, however, were markedly different--- particularly their staging of race and gender. Cruz became "the lady," while La Lupe's performances were marked by frenzy and excess. Both also worked within established racial codes that would seek to constrain performative possibilities for black women. They simultaneously, although in different ways, played into and challenged those racial codes thereby contributing to this uniquely American sound.
\end{abstract}

Keywords: Salsa, Celia Cruz, La Lupe, gender and music, mulatez

While there are ongoing discussions among scholars as well as performers regarding Salsa's influences and roots, the one point of consensus is that New York City is its birthplace. The city provided a space where various groups and communities came together in close proximity, promoting vigorous exchange between musicians from Puerto Rico, Cuba and other locations in the Caribbean as well as those rooted in African-American forms such as Jazz. After World War I (WWI), migration from Latin America and the Caribbean to New York intensified but

had not yet split into countries of origin. Puerto Ricans, Cubans, Mexicans, and other "Latinos" lived in the same neighborhoods and attended the same social clubs ... Musical groups had members from diverse national backgrounds and those mixtures eventually gave way to the notions of "Latin" and "Latino" as broad-spectrum terms. (Quintero-Rivera and Márquez 2003: 85-86)

The Puerto Rican community, which began to establish itself in the city after WWI, grew to large numbers due to migration from the island following WWII. A US-formulated project to industrialize the island, Operation Bootstrap, led to the displacement of rural populations to urban centers, creating economic pressures for 
further migration from the island to New York City. This massive flow of people is but one link in a chain of migrations and displacements that mark the history of the Caribbean. In the years following WWII, this history led to a confluence of multiple flows and migrations into New York City as the Puerto Rican migration, although the largest in numbers, was joined by others from different points in the Caribbean and Latin America. In terms of music, the city served as a space for cultural contact not only between musicians from various points in the Caribbean but between consumers as well. These factors meant that to attract diverse audiences and to keep them coming back for more, bands played a mixture of rhythms, even if "throughout the 1930s, '40s, and '50s, Cuban styles (son, rumba, conga, guaracha, mambo, and chacha) dominated" (Washburne 2008: 14). The dominance of Cuban rhythms, particularly son, can also be attributed to these Caribbean currents, as son had already traveled throughout the region and had been adopted, changed, and rearticulated prior to arriving in New York.

The fact that Salsa as a cultural expression is one marked by contact and exchange, the experience of migration, and remapped affiliations paradoxically makes it a uniquely "American Sound." I use the word paradoxically because its emergence and appeal is also based on a self-conscious resistance to U.S. hegemony as much as it is a product of the very imperialism it seeks to contest. Salsa sonically contests US hegemony through its instrumentation, which sought to embrace and transform various musical traditions as well as represent the brash sound of the barrio. Furthermore, its use of Spanish stages linguistic resistance to an American identity that is constructed as monolingual. Aparicio defines Salsa as:

a syncretic art form that originated in the barrios of New York City. A conjunction of Afro-Cuban music (el son) and rhythms, of Puerto Rican bombas and plenas, and of African American jazz instrumentation and structures, salsa music has become the quintessential musical marker of latinidad in the United States and in Latin America. (1994: 662)

Salsa's prominence as a locus of identity for many Latinos as well as its transnational implications are also important as it cannot be limited to a musical definition. It became identified with Latino urban communities in New York and other U.S. cities and the Caribbean.

Salsa's expansion outside of New York to other US cities and Latin America was due to both deliberate marketing on the part of the record label Fania as well as audience response to this form of cultural expression. The label made a strategic effort to "Latinize" Salsa so as to make it "reflect the wide variation of Latin American cultures and social experiences as a way to better sell it in these potential markets.” (Padilla 1989: 34) The genre's appeal to latinidad was inherent in its formation. Taking the clave as its rhythmic base, the form not only allowed for, but actually encouraged the incorporation of various styles and traditions from several 
geographic points of origin. In addition, Salsa performers sang (and continue to sing) in Spanish. While this has limited Salsa's ability to "crossover," it functions as an obvious marker of Latino identity as well as highlighting the strongest point of commonality in latinidad or pan-latino consciousness.

Scholarship on Salsa has grown in the past fifteen years, yet the role that female performers have played, and continue to play, in the development of the genre has been largely ignored. The lack of representation of female performers in the scholarship is no doubt rooted in the overall underrepresentation of women in the Salsa recording industry. As a step toward retracing the genealogy of Salsa matrilinealy, this article looks at two women who became stars in the industry: Celia Cruz and La Lupe. Both, in different ways, constructed stage personas that simultaneously evoked and resisted gender and racial stereotypes. Although the degree to which Cuban musicians and Cuban musical traditions shaped the development of Salsa is a point of ongoing debate, there is consensus that Cuban music, particularly but not exclusively son, is a major contributor. Given that both of these performers began their respective careers in Cuba, they also had to create a space for themselves by re-territorializing and re-articulating their own musical traditions to fit more fully into Salsa's pan-latino project. In doing so, they contributed to and enriched the form. For Celia Cruz, this re-territorializing meant maintaining an adherence to Cuban traditional forms such as son while incorporating other styles and rhythms. Her re-articulation of a pan-latino identity is more overt in her lyrics than her arrangements. In contrast, La Lupe re-territorializes the scripting of la mulata garnered from Cuban iconography and re-articulates it through her corporeal staging and hybridized rhythms as well as through her singular voice that projects excessive affect and marginalized class affiliations.

Although Celia Cruz and La Lupe were contemporaries, their performance styles as well as their on and off-stage personas were markedly different. I begin my discussion with Cruz, as she is far better known, particularly outside of Salsa music circles. Born Ursula Hilaria Celia Caridad Cruz Alfonso on October 21,1924 in Havana, Cuba, Celia Cruz would go on to have a sixty year-long musical performance and recording career. At the time of her death in 2003, she was the undisputed Queen of Salsa, mourned by fans throughout the world. The exceptionality of Celia Cruz's career is irrefutable, particularly given that her gender and race made her an unlikely star in Salsa music. Furthermore, the longevity of her career makes her atypical in any musical genre.

In 1948 Cruz had her first international tour to Mexico and Venezuela performing as a vocalist for the Mulatas del Fuego. As the exoticizing title of the group suggests, the draw of this act was the female black dancers who performed scantily clad in bikinis. In contrast to the dancers, Cruz wore modest ball gowns or dresses and barely moved as she sang. The Mulatas del fuego's performance, for the most part, played into stereotypic representations of Black female bodies as spectacle, representations based in large part on racist discourses ranging from pseudoscientific studies of the 
nineteenth century to the mythic "Venus Noir" (Black Venus) of the Francophone Caribbean. While nineteenth century medical discourse linked the Hotentott woman and the prostitute by pathologizing both blackness and female sexuality, the Black Venus duplicates this pseudoscientific pathologizing with minor alterations. Naderveen Pieterse summarizes the relationship between the two in writing: "The lyrical view of the Black Venus was not fundamentally different from the medical perspective [...] but the attitude toward sexuality itself was different - not hostile" (1992: 183).

Cruz distances herself from these representations or expectations through her performance. While her wardrobe and stage persona would undergo several changes over the years, becoming more and more outrageous as she aged, as her earliest performances with the Mulatas del fuego showed, she was always the "lady." If audiences expected black female bodies on stage to signify unbridled sexuality, Cruz's persona offered an alternative. In available footage of these performances we see Cruz physically removed from the dancers - literally set apart, standing above them on an elevated stage platform. The dancers draw the gaze with their movements and expose their bodies as sexualized spectacle while Cruz is practically standing still, her body on display as feminine but not sexualized. Arguably, Cruz selfrepresentation as a gendered, racialized subject (and object) as sexually unavailable would prove to be an asset as she aged and continued to record and perform.

As the lead vocalist of Sonora Matancera, Cruz's stage persona changed. In contrast to her earlier performances, she began to use her body more freely, moving about the stage and dancing. While Cruz was not the first female lead vocalist for the group, she was unique in that, to quote Sublette, "to see a girl singing kinetic, rhythmic music in front of a band was unusual in Cuba, let alone a black girl, let alone one obviously not hired for her looks" (2004: 575-76). During her time with the group, Cruz's stage persona matured. The counterpoint between tradition and innovation was reflected in the aesthetic choices she made on stage as much as how she behaved off stage. An apt summation by Sublette is that she "was earthy but not nasty. She was from a working-class background, but she wasn't from the solar. She was a guarachera, but she was a straight arrow who embodied polite, decent values [...] Though she sang to the orishas on stage and in the studio, she was a church going Catholic girl [...] with Celia singing, Sonora Matancera sounded blacker” (2004: 575). Her visual and aural self-representation demonstrated an awareness of gender and racial codes but managed to stage them in alternative ways.

Shortly after the Cuban Revolution of 1959, Cruz left the island to tour Mexico with Sonora Matancera and in 1962 she left the group and went to New York. The city, which she claimed as her home until her death, provided the ideal crossroads for musical exchange. Cuban musicians had traditionally spent time there and the Puerto Rican community contributed greatly to the mix. By the 1970s she was recording with Fania, a major label that was to become the launching pad for Salsa as a musical genre. 
Cruz is a perfect fit in the context of Salsa. Musically, the clave is as central in Cuban music as it is in Salsa. Linguistically, the predominance of Spanish also marked Salsa music and Spanish was not only Cruz's first language but her only language as she often unapologetically told her audience, in a heavy accent, "my English is not very good looking". Furthermore, since her music had already become reterritorialized as belonging to the whole of the Caribbean, it was not much of a stretch to make its transnationalism reach further to the whole of the Americas. Cruz's music selection from the late 1960s through the 1980s is notable in its inclusion of the whole of Latin America and its attention to lyrically speaking directly to Latinos in the U.S. She recorded and performed merengues from the Dominican Republic, jaropos from Venezuela and rancheras from Mexico, always using musical arrangements that would make her version of those songs her own. She even recorded the song "Toro Mata," an Afro-Peruvian song which became the first in that genre to be popularized outside of Peru. These types of selections and arrangements highlight the role of migration as they move from their point of origin to be transformed and redistributed as something both new and familiar. Cruz's performances of these songs further promote musical migrations as they take on new nuances and meanings through novel arrangements as well as new audiences. Cruz's reappropriation and reterritorialization of these songs fits well within Salsa. In terms of its own grassroots development as well as recording labels' deliberate marketing strategies, Salsa as an artistic form is centered on the experience of migration, cultural contact and transformation.

Lyrically, her music selection demonstrated a conscious effort to highlight points of commonality among and between different parts of the Caribbean and Latin America. The song "Soy Antillana," for example, which she recorded in 1966 proclaims "Lo mismo yo soy cubana, dominicana que borincana...no debe haber separación" [I'm just as well Cuban, Dominican or Puerto Rican...there should be no separation]. The song even goes on to state, "y aunque la bella mar nos separa formamos juntas una nación" [and although the beautiful sea separates us we form together one nation]. The song reterritorializes the "imagined community" of nation to include the whole of the Hispanophone Caribbean, proposing a transnational affiliation based on common cultural traits and rhythms.

Cruz's performance of the song "Contrapunto musical” further demonstrates her reteritorrializing of herself and her music. The song describes the interplay between various Hispanophone Caribbean rhythms as a counterpoint, or contrapunteo, with herself at the center bringing all of them together. In her usual promotion of harmony and unity over division and confrontation, the song opens with "Caballeros esto no es para pelear, ni pa' que nadie diga que esto es mejor que el otro" [Gentlemen this is not to fight over, nor for anyone to say that this is better than the other]. The lines diffuse national divisions, synthesizing differences to bring about figurative and literal harmony. As a migratory subject, Cruz situates herself, and her song, as emblematic of music, and Salsa music in particular, as syncretic in nature. The verses 
go on to present various rhythms in dialogue with one another with lines such as " $\mathrm{La}$ bomba cumbia y plena empezaron a chismear porque no se explicaban como se ha colado el rap" [Bomba, Cumbia and Plena began to gossip 'cause they couldn't explain how Rap had snuck in.] Bomba and Plena are Puerto Rican in origin, while Cumbia is Colombian. Including these along with Cuban forms such as "guaracha $y$ son" make all of them part of the Caribbean "family" the song promotes.

The lyrics go on to include "rap" into the fold, even as they assert that "se ha colado" [it snuck in]. This is significant in several ways. On the one hand, it embraces a form that comes from the U.S. and more widely, though not exclusively, performed in English. In doing so, it recognizes the U.S., or at least parts of it, as connected to the Hispanophone Caribbean. It furthermore lays claim to Latino contributions in the development of Rap (Hip Hop) in urban centers where migration has brought Latino, African-America and Francophone and Anglophone Caribbean youths into tight cultural proximity and exchange. The incorporation of musical change, innovation and syncretism is also signaled and celebrated in the lines "el bochinche que tenían el bolero y la guajira porque en ritmos caribeños se coló la batería" [the uproar between the bolero and the guajira was because the drum set had snuck into Caribbean rhythm]. If the drum set, like Rap, snuck into this musical neighborhood, it is no less a part of it. Like Rap, the drum set similarly comes from a U.S. influence: Rock and Roll. And like Rap, Rock and Roll has roots in migration and cultural contact. The song's all-inclusive embrace also goes beyond salsa's own self-defined limits. Although it is a genre born of cultural contact, it promotes itself as an alternative for youths in resisting U.S. hegemony through the reification of a Latino identity. As such, it implies a rejection of U.S. mainstream music exemplified by Rock and Roll. In this song, Cruz lyrically and rhythmically resolves the oppositional tension, not by making Salsa more “American," but rather by making U.S. popular music part of Salsa.

The video for "Contrapunto musical" reinforces the lyrics with a multiracial, multigenerational cast. The setting is a working class neighborhood in an unidentified Caribbean city. The common unity represented in the lyrics is also visually represented through cultural markers other than music such as dominoes. The video culminates in a street party where all sectors are integrated in celebration. The scene, and the song as a whole, reinforces the often played trope of music providing symbolic unity that erases or subsumes differences. Laying claim to a broader Caribbean context as "family" and "home", however, also ameliorates the migrant experience. That is, away from Cuba, a new "home" is constructed through a music rooted in a Cuban tradition but simultaneously embracing other influences.

The song "Latinos en Estados Unidos" provides a similar vision for pan-latino consciousness, but places it within the geopolitical borders of the U.S. The song points to a common ancestry and history with the line "venimos de la América india, del negro y del español" [we come from the Indian America, from the Black and the Spanish], and imagines a nation within a nation by proclaiming "casi somos una 
nación" [we are almost a nation]. While the song has a strong political message with the repeated lines "vamos a unirnos...Que en la unión está la fuerza" [Let's unite...In unity lies strength] it also, in keeping with Cruz's usual distance from confrontational politics, praises the U.S. as it advises Latinos to be "agradecidos con esta tierra de paz," [grateful to this land of peace]. In contrast to other Salsa performers who sang directly to themes of social injustice, imperialism or exploitation, Cruz's pan-latino consciousness stressed unity, points of commonality and pride. It is more affirmational than oppositional. With songs such as these, as well as her playful commentary on stage during performances, Cruz consistently promoted pan-latino identification as a unifying force. It is interesting to note that in calling for pan-latino unity Cruz is participating in a long tradition in Latin American intellectual history. Perhaps the most obvious, especially in Cruz's context, is José Martí’s essay “Nuestra América" ["Our America"]. What is different in Cruz is that Martí contrasts "Our America" or Latin America to "the America which is not ours" or the U.S, while Cruz is re-locating "Our America" within the U.S. Her ethnic affirmation provided an open embrace to all Latinos and Latin Americans, but it also provided and open invitation for her growing and expanding audience to in turn embrace her and her music.

Cruz's continuous reterritorializing of her music, and by extension herself, is clearly seen in her 1974 performance with the The Fania All Stars in Zaire (now Congo) as part of the musical festival that accompanied the "Rumble in the Jungle" boxing match between George Foreman and Muhammad Ali. The three-day concert featured superstars of soul and blues such as B.B. King and James Brown, effectively staging in Africa a festival of African Diaspora music. Cruz performed a Salsa arrangement of the traditional Cuban "Guantanamera" as well a long version of the hit "Quimbara" which included instrumental improvisation and had the feel of a "descarga" or jam session. She wore a flashier, metallic version of a rumbera dress which is traditionally form-fitting and flared at the bottom with ruffles at the hem and arms. In this performance we can see Cruz giving an energetic and joyful rendition of the song, her body in constant motion to the music while her voice amplified to the last seat in the stadium. She is wearing a wig, but unlike the outrageous wigs she would use in her later years, this one simulated hair tightly pulled back in an elaborate chignon. In keeping with her usual stage persona, she is sensual but not sexy, feminine but not seductive. The audience's reaction is perhaps what is most telling about Cruz on stage, wherever that stage may be. With their cheers and full participation we can interpret that to the audience, this music and this woman leading vocals and taking center stage felt familiar and comfortable. The performance in Zaire is just one example of how Cruz, as the Queen of Salsa, greatly contributed to the genre's internationalization which "has led to [Salsa] being constantly located, dislocated and relocated and therefore continually in a process of transformation. This process, however, is also marked by the maintenance of certain codes and conventions” (Román-Velázquez 2002: 210). True to Cruz’s mastery of navigating 
the counterpoint between tradition and change, she stayed one step ahead of, or led the way, in a series of transformations while retaining identifiable elements that mark her music as simultaneously Cuban.

While Cruz was either fifty or fifty-four years old for the performance in Zaire, in the film footage she appears ageless -clearly not a young woman but not what mass media portrays as "middle-aged," and not what in the music industry would be considered "old.” As Negrón-Montaner aptly points out:

Undoubtedly, Celia's talent in fusing a wide range of sounds played a large role in her ability to retain salsa's royal title for more than fifty years. Yet in an era when bodily image, not vocal ability, often sells more CDs, Celia had to creatively solve another matter to ensure long-term success: that of not "looking good" as a performer. At the height of her global fame, for instance, Celia was not beautiful in a conventional sense, slim or young. (2007: 67-68)

Arguably, what at first glance appears to be a strike against her staying power as a performer, namely her looks, can be viewed through the lens of her career trajectory as a whole as one of the reasons she was able to retain her audience's attention. Because Cruz was, even in her youth, not conventionally beautiful, she was able to exclude herself from being identified as a "sexually tantalizing" performer. That is, because she built her career, from the outset, as a first rate vocalist and charismatic performer and not a sex object, she was able to make transitions later in her career still relying on what audiences were drawn to all along: her talent. That is not to say that Cruz had no part in "creatively" solving the matter of how to retain visibility and relevance in an industry that overvalues youth and conventional representations of beauty. As has been argued thus far, she deliberately cultivated her image both on and off the stage as well as making use of her repertoire to broaden her appeal. But as she aged, she was able to continue her negotiation of tradition and change by refashioning herself while remaining true to her musical roots and performance style.

La Lupe's performance of race and gender stands in contrast to Cruz. Although they were contemporaries and expressed respect for each other's talent, they also acknowledged that as performers they were "different." While Cruz was "the lady", restrained, professional and removed from the eroticized male gaze, La Lupe wept, bit herself, laughed, scratched her face, tore at her clothes, shouted obscenities, moaned, and threw her shoes into the audience, or, more commonly, used them to pummel her piano player. Furthermore, her voice, commonly described as "screaming, disorderly, and disrespectful," was often associated with chusmería, or low class (Rondón, 1980: 46; Muñoz 1999: 182). She settled in New York City in 1963, performing with famed percussionists such as Mongo Santamaría and Tito Puente. Her repertoire included passionate interpretations of boleros, or love songs, to fusions of Afrocuban music and jazz as well as forms that have come to be identified 
as Salsa. Critics such as César Miguel Rondón have recognized La Lupe’s contributions in the development of the genre in New York. As Aparicio summarized, La Lupe "represents the bridge between the big band sound and the barrio, inscribing in her performances as well as in her modulations the "grito de guerra," that salsa has represented as the music of marginalized sectors" (1998: 179). Reading La Lupe's performances in the context of Cuban constructs of race and gender reveals that she uses and subverts stereotypic depictions and readings of "la mulata." Her performances, marked by affective and sensual/sexual excess, disrupts discourses on la mulata by, in a sense, giving the audience "too much" of what it expects.

In the nineteenth century, when Cuba was still under colonial Spanish rule, the figure of la mulata became a pervasive subject of the literature, painting, advertising and music on the island. While the mulata was, on the one hand, held up as symbolic of the emerging Cuban nation, and Cuban culture, she was in the eyes of the racist, white male dominated society invisible and powerless. Vera Kutzinski succinctly summarizes this phenomenon, writing, "In the case of the mulata, high symbolic or cultural visibility contrasts sharply with social invisibility" (1993: 7). If the mulata's body was promoted as symbolic of Cuba's version of mestizaje or racial mixture and therefore the figurative site of racial and cultural harmony and synthesis- it was also a site that lacked subjectivity, functioning as a mere object and spectacle for the exclusive pleasure of the male gaze. La mulata also seemed to embody interracial sexuality, cross-racial desires, and the sexualized connotations of racial hybridity, as Arrizón (2006) and others have argued.

If colonialist discourses stereotyped the black female as atavistic, an icon of deviant sexuality, in Cuba, this discourse was projected specifically onto the body of la mulata. In light of this, what can we make of La Lupe's excessive exhibition of her body and sexuality? Jose Piedra and Judith Bettelheim, writing about rumberas and Cuban carnaval dancers respectively, shed partial light on this question. Bettelheim proposes

that rather than assuming the role of victim, some African and African-American women have asserted their sexuality in performance as oppositional practice. They manipulate a colonial or racist or patriarchal authority by means of that which is often used to subjugate them: their sexuality. (1997:196)

Piedra offers a complimentary position in describing the rumbera's performance as “offensive display and defensive disguise” (1997:116-117). La Lupe’s performance can be seen as engaging both of these positions. It manipulates and plays upon representations of la mulata, taking them over the top to the point of rupture (or rapture), where power hierarchies are reversed. La Lupe's interpretation of the song "Besito Pa Ti" [Little Kiss for You] demonstrates this reversal. The besito, or little kiss, in the title is comprised of "azúcar, canela y anís" [sugar, cinnamon and anis], making it sweet and intoxicating. The reference to sugar is significant: azúcar is the 
prime Cuban export: as a final product, it is white, but it was historically derived from black labor. Cinnamon is similarly symbolic in that it is commonly used as descriptive of a mulata's skin. The bilingual song describes the kiss, in English, as "honey right from the bee", forging a semantic connection to sex; yet, the besito, or kiss, is also linked to the Santería deity of Ochun through honey, one of the Orisha's favored offerings. This symbolically loaded besito is, in the title, offered "pa ti" [for you], but as the song progresses, it becomes obvious that the embodied recipient of besitos is La Lupe herself: as writer and singer, La Lupe transforms "Besito Pa Ti" into "besitos pa mí" [kisses for me]. Before the song even begins, we hear La Lupe laughing, followed by a soft "a-a-ay!”. As the song progresses, her moans, interjected between verses, grow in intensity and volume. At one point she declares, "Don't worry baby. I'm coming baby, wait for me, just one more little kiss.” After the next verse, the tone becomes increasingly erotic, even aggressive in the line, "Kiss me once more / just once again / keep kissing darling 'til I tell you when" followed by a long series of moans, groans, and calls of "a-a-ay, a-a-ay." Thus, while the song claims to be about giving besitos, it's really, as performed by La Lupe, all about getting them - when, how, and for as long as she desires.

One of her own compositions, "Canta Bajo," is similarly explicit. The song beckons the base to sing for her while she moans. Unlike "Besito Pa Ti," which contains several verses of lyrics, "Canta Bajo" is almost devoid of words, consisting primarily of kisses, sighs, and groans, interrupted by spoken lines such as "let me touch your base," "let me put my little finger on it, oh, a-a-y." Through this song, we can aurally experience what her visual performance communicated; namely, La Lupe's definition and expression of sexuality on her own terms. Interestingly, the few lyrics in "Canta Bajo" are in English even if the title is in Spanish. Arguably, one of La Lupe's most notable qualities is her disruption of hierarchies and boundaries in terms of gender and race. Yet, her use of bilingualism demonstrates another boundary crossing and that is the linguistic. As has been previously mentioned, Salsa favors and even promotes hybridity, yet it maintains Spanish as a marker of pan-latino identity and resistance against U.S. hegemony. La Lupe, however, violated this unspoken rule and recorded bilingual songs such as "Canta Bajo." Another bilingual track from La Lupe that merits attention is her interpretation of "Fever," a song originally recorded by Little Willie John in 1956 but made famous by Peggy Lee. Within the crowded field of diverse artists who have covered the song - Elvis Presley, James Brown, Madonna, Beyonce, and others - La Lupe's version stands out. Even before the first verse begins, La Lupe makes the song her own, laughing and interjecting "groooveh, baby, grooveh" over the song's original finger snapping. She sings the first verse in heavily accented English, rolling the ' $r$ ' in fever and interjecting a sultry "ay" occasionally. The effect is playful and sexy. After the first verse, Spanish takes a larger role as she switches back and forth between English and interjected Spanish lines. 
Toward the end of the song, the musical arrangement shifts, becoming a Bugalu. The genre, also referred to as Bugalú or Latin Boogaloo, was popularized in the 1960s, predating the commercial salsa boom. It was a mixture of Latin music and Soul using bilingual, Spanish and/or English language lyrics (Sublette, "Bugalu on Broadway"). It was predominantly but not exclusively played by very young groups. Its sudden demise by the late 1960s is often attributed to the control of recording studios and performance venues by older musicians and promoters who viewed it as too much of a fusion with R \& B and Soul. Furthermore its frequent use of English ran counter to the by then growing promotion of Spanish as an expression of cultural unity among diverse Latino communities. La Lupe's incorporation of Bugalu into her rendition of "Fever" is not only instrumental. As the song rhythmically shifts, its structure changes into a call and response with La Lupe singing "come on and dance" and the band members responding "El Bugalu," and once the rhythm has sped up into a bilingual, fusion dance frenzy, it ends with her pensioned shout "Feeee-verrrr."

Like Celia Cruz, La Lupe incorporated varying forms and genres into her repertoire. The difference here is that La Lupe wandered further into R \& B, Jazz, and Soul than did Cruz. Moreover, her use of bilingualism, while separating her from the salsa mainstream, connected her music more fully with Latino audiences in the U.S. accustomed to living in and between two languages. Much like her performance of race and gender is situated in the liminal, so too is her performance of ethnic identity within the U.S. as her linguistic choices as well as her incorporation of musical forms, particularly from African American sources, demonstrates. Augusto Puleo has observed that,

Celia Cruz, la India, and female blues singers have broken out of the boundaries of the home and taken their sensuality and sexuality out of the private and into the public. For these singers were/are overflowing with talent and often stunning in appearance; in fact, their presence has often elevated them to being referred to as the Queen, the Goddess, Empress, la Reina. (1997: 231)

While La Lupe is not explicitly included in this list, she certainly qualifies, and was, in fact, referred to a La Reina/The Queen, as the titles of two of her albums -La Lupe es La Reina and La Lupe, Queen of Latin Soul- claim. Her obituary in The New York Times likewise referred to her as "The Queen of Latin Soul." Her erotization of herself gave her power, and unlike the sex appeal of la mulata which is predicated on her exploitation, La Lupe stages her "offensive display" as transgression and resistance.

Celia Cruz and La Lupe both reached stardom in a musical genre that has proven inhospitable to female performers. Cruz became the undisputed "Queen of Salsa" while La Lupe became known as the "Queen of Latin Soul.” While both faced similar projections in terms of expectations bound by gender and racial constructs, they chose to "stage" their identities in radically different ways. Their contributions to 
Salsa not only feminized this masculinist musical genre, but impacted its very sound. On the one hand, Cruz defined the traditional matancera or traditional style of Salsa, while La Lupe personified the brash sound of the barrio identified with salsa dura or "hard salsa." As influential Salsa performers, both left an aural imprint on the American soundscape, one that helped redefine American music to include linguistic and rhythmic variation.

\section{REFERENCES}

Aparicio, Frances (1998). Listening to Salsa: Gender, Latin Popular Music, and Puerto Rican Cultures. Hanover: Wesleyan U P/ UP of New England.

Aparicio, Frances (1994). "Así Son”: Salsa Music, Female Narratives, and Gender (De)Construction in Puert Rico. Poetics Today 5.4: 659-684.

Arrizón, Alicia (2006). Queering Mestizaje: Transculturation and Performance. Ann Arbor: U of Michigan P.

Bettelheim, Judith (1994). Ethnicity, Gender, and Power: Carnaval en Santiago de Cuba. Negotiating Performance: Gender, Sexuality, and Theatricality in Latin/o America. Eds. Diana Taylor and Juan Villegas. Durham: Duke U P, 176-212.

Celia Cruz and The Fania All Stars-Quimbara-Zaire, Africa 1974. Youtube. Youtube.com (Accessed March 1, 2011).

Celia Cruz y Las Mulatas del Fuego. Youtube. Youtube.com. (Accessed March 1, 2011).

Cruz, Celia (2000). Contrapunto musical. Siempre Viviré. Sony Music, CD .

Cruz, Celia (1981). Rondón Latinos en Estados Unidos. Celia y Willie. Vaya, LP.

Cruz, Celia (1974). Toro Mata. Celia y Johnny. Vaya, LP.

Kutzinski, Vera (1993). Sugar's Secrets: Race and the Erotics of Cuban Nationalism. Charlottesville: U P of Virginia.

La Lupe (1977). Besito Pa' Ti. Unica en su clase / One of a Kind. New York: Tico Records, LP.

La Lupe (1977). Canta Bajo. Unica en su clase / One of a Kind. New York: Tico Records, LP.

La Lupe (1968). Fever. Queen of Latin Soul / Reina de la Canción Latina. New York: Tico Records, LP.

Martí, José [1891] (1991). Nuestra América. Havana: Centro de Estudios Martianos, Casa de las Américas.

Muñoz, José Esteban (1999). Disidentifications: Queers of Color and the Performance of Politics. Minneapolis: U of Minnesota P.

Naderveen Piaterse, Jan (1992). White on Black: Images of Africa and Blacks in Western Popular Culture. New Haven: Yale UP. 
Negrón-Montaner, Frances (2007). Celia's Shoes. From Bananas to Buttocks: The Latina Body in Popular Film and Culture. Ed. Myra Mendible. Austin: U Texas P, 65-86.

Padilla, Felix (1989). Salsa Music as Cultural Expression of Latino Consciousness and Unity. Hispanic Journal of Behavioral Sciences 11.1: 28-45.

Piedra, José (1997). Hip Poetics. Every-Night Life: Culture and Dance in Latin/O America. Ed. Celeste Fraser Delgado and José Esteban Muñoz. Durham: Duke U P, 93-140.

Puleo, Augusto (1997). Una verdadera crónica del norte: Una noche con La India. Every-Night Life: Culture and Dance in Latin/O America. Ed. Celeste Fraser Delgado and José Esteban Muñoz. Durham: Duke UP, 223-238.

Quintero-Rivera, Ángel and Roberto Márquez (2003). Migration and Worldview in Salsa Music. Latin American Music Review/Revista de Música Latinoamericana 24.2: 210-232.

Román-Velázquez, Patria (2002). Locating Salsa. Popular Music Studies. Ed. Keith Negus and David Hesmondhalgh. London: Arnold, 210-22.

Rondón, Cesar Miguel (1980). El libro de la salsa: Crónica de la música del Caribe urbano. Caracas: Editorial Arte.

Sublette, Ned (2004). Cuba and its Music: From the First Drum to the Mambo, Vol. 1.Chicago: Chicago Review.

Sublette, Ned (2013). Bugalu on Broadway: The Dawn of Salsa in New York City. Red Bull Music Academy Magazine. $<$ www.redbullmusicacademy.com/magazine> (Accessed July 20 2013).

Washburne, Christopher (2008). Sounding Salsa: Performing Latin Music in New York City. Philadelphia: Temple UP. 